\title{
The use of morphometric characters to discriminate specimens of laboratory-reared and wild populations of Gyrodactylus salaris and G. thymalli (Monogenea)
}

\author{
Andrew P. Shinn ${ }^{1}$, Haakon Hansen ${ }^{2}$, Kjetil Olstad $^{2}$, Lutz Bachmann ${ }^{2}$ and Tor A. Bakke ${ }^{2}$ \\ ${ }^{1}$ Institute of Aquaculture, University of Stirling, Stirling FK9 4LA, Scotland, UK; \\ ${ }^{2}$ Zoological Museum, The Natural History Museums and Botanical Garden, University of Oslo, Oslo, N-0562, Norway
}

Key words: Gyrodactylus salaris, parasite, salmonids, taxonomy, morphology

\begin{abstract}
Gyrodactylus thymalli Žitňan, 1960 and G. salaris Malmberg, 1957 have an indistinguishable ribosomal internal transcribed spacer (ITS) DNA sequence, but exhibit surprisingly high levels of intra- and interspecific sequence variation of the mitochondrial cytochrome oxidase I (CO1) gene. To test whether different populations of these reportedly very similar species could be discriminated using morphometric methods, we examined the morphometry of four different populations representing different mitochondrial clades. Twenty five point-to-point measurements, including five new characters of the attachment hooks, were recorded from three Norwegian laboratory populations ( $G$. salaris from the Rivers Lierelva and Rauma, and G. thymalli from the River Rena), and from one wild population of $G$. thymalli from the River Test, UK. The Norwegian populations were kept under identical environmental conditions to control for the influence of temperature on the haptoral attachment hooks. Data were subsequently subjected to univariate and linear stepwise discriminant analyses. The model generated by the linear stepwise discriminant analysis used 18 of the 25 original variables, the first two roots accounting for $96.6 \%$ of the total variation between specimens. The hamulus shaft length accounts for $66.7 \%$ of the overall correct classification efficiency. Based on morphometry, all specimens were assigned to the correct species. Apart from three specimens of G. salaris from the River Lierelva population which were misclassified as belonging to the G. salaris Rauma population, all specimens were assigned to the correct population. Thus, populations of Gyrodactylus identified by mtDNA can also be discriminated using morphometric landmark distances.
\end{abstract}

In the mid-seventies Gyrodactylus salaris Malmberg, 1957, an ectoparasite originally described from Atlantic salmon (Salmo salar L.) parr from the Hölle laboratory, Indalsälv, Sweden, was recorded at the Forsøksstasjon for laks (FFL), Sunndalsøra, Norway. G. salaris has since been found in more than 40 Atlantic salmon rivers in Norway where it has caused significant damage both in ecological and economic terms (Johnsen et al. 1999). G. salaris has also been recorded from several rainbow trout farms and salmon hatcheries in Scandinavia and continental Europe (Malmberg and Malmberg 1993, Mo 1994, Koski and Malmberg 1995, Johnsen et al. 1999, Buchmann et al. 2000). The benign species $G$. thymalli Žitňan, 1960, originally described from grayling, Thymallus thymallus L., from the Rivers Hron and Hnilec, Slovakia (Žitňan 1960), is morphologically very similar to G. salaris (see Ergens 1983, McHugh et al. 2000, Shinn et al. 2000). G. thymalli has been recorded from Fennoscandia, Russia, continental Europe and the UK. Morphometric discrimination of G. salaris and $G$. thymalli is possible using sophisticated statistics (McHugh et al. 2000), but this study was based on a limited number of $G$. thymalli specimens, and on $G$. salaris specimens that were pooled from several populations across Scandinavia. However, these species have been shown to have different host preferences
(Soleng and Bakke 2001, Bakke et al. 2002, Sterud et al. 2002).

The ribosomal ITS region of both $G$. thymalli and $G$. salaris collected from different salmonids over a wide geographical range have been found to be almost identical (Matejusová et al. 2001, Zietara and Lumme 2002), indicating conspecificity of these two species. Sterud et al. (2002) found small but consistent differences between $G$. salaris and G. thymalli in the nucleotide sequences of the intergenic spacer (IGS) of the ribosomal DNA cassette. Surprisingly high levels of intra- and interspecific differentiation of the mitochondrial cytochrome oxidase I gene (CO1) in populations of $G$. salaris and G. thymalli populations have recently been detected (Hansen et al. 2003, Meinilä et al. 2004). Several clades of mitochondrial haplotypes were described, specific for either G. salaris or for G. thymalli, with no overlap between them. We therefore studied whether populations of G. thymalli and G. salaris that bear mitochondrial haplotypes from different/distinct clades could be separated by morphometry. In addition, to the morphometric parameters currently in use for Gyrodactylus taxonomy we wanted to assess whether new morphometric characters would increase the discriminatory

This paper was presented at the 6th International Symposium on Fish Parasites in Bloemfontein, South Africa, 22-26 September 2003.

Authors for correspondence: (1) A.P. Shinn, Institute of Aquaculture, University of Stirling, Stirling FK9 4LA, Scotland, UK. Phone: ++44 1786 467 925; Fax: ++44 1786472 133; E-mail: aps1@stir.ac.uk (2) H. Hansen, Zoological Museum, The Natural History Museums and Botanical Garden, University of Oslo, Oslo, N-0562, Norway. Phone: ++47 2285 1751; Fax: ++47 2285 1837; E-mail: haakon.hansen@nhm.uio.no 
power. Previously it has been shown that some morphometric characters of gyrodactylids are influenced by temperature (e.g. Mo 1991a, b, c), and therefore laboratory strains kept under constant conditions were studied. This study aims to improve the methodology based on landmark distances as a tool for discriminating between populations of $G$. salaris and $G$. thymalli.

\section{MATERIALS AND METHODS}

Gyrodactylus populations. Specimens of native populations of Atlantic salmon, Salmo salar, from the Rivers Lierelva (SE Norway) and Rauma (W Norway) and grayling, Thymallus thymallus, from the River Rena (SE Norway) were collected and transported to the aquaria at the Zoological Museum, NHM, University of Oslo. The fish were then lightly anaesthetized and examined for the presence of Gyrodactylus. Two cultures of $G$. salaris (one from each of the two salmon populations) and a culture of $G$. thymalli (from grayling) were established by transfer to naïve hosts and maintained on their respective hosts for approximately 6 months under identical laboratory conditions (in separate tanks, size: $1 \times 1 \times 0.3 \mathrm{~m}$ water level; flow-through charcoal-filtered de-chlorinated water adjusted to a temperature of $10-12^{\circ} \mathrm{C}$ ). The cytochrome oxidase I sequences of these populations are presented in Hansen et al. (2003). During routine electrofishing surveys in the River Test in the south of the UK, infected grayling were collected and examined at the Weymouth Laboratory, CEFAS for the presence of specimens of Gyrodactylus. Ammonium picrate glycerine mounted specimens of $G$. thymalli deposited in the CEFAS parasitology collection from surveys conducted in April 1997 and 1999 were borrowed and analysed alongside the Norwegian material. The water temperatures in the River Test at the times of collection were $12.4^{\circ} \mathrm{C}$ and $9.4^{\circ} \mathrm{C}$, respectively.

Morphometric analysis. Approximately fifty specimens of each Gyrodactylus strain were removed and air-dried onto glass slides to ensure that flat preparations were obtained. For analysis, the specimens were then rehydrated by fixation in situ with a single drop of ammonium picrate glycerine and a coverslip placed over the worm. Specimens were photographed using a JVC KY-F30B 3CCD camera with an interfacing $\times 2.5$ top lens fitted to an Olympus $\mathrm{BH} 2$ compound microscope under a $\times 100$ oil objective, and measured using Zeiss KS300 iC/Windows Release ver. 3.0 (1997) (Carl Zeiss Vision GmbH, München, Germany/Imaging Associates Ltd, Thame, Oxfordshire, UK) software. A total of 25 point-topoint measurements were made on each specimen. The measurements used were: hamulus $(\mathrm{H})$ : total length $(\mathrm{HTL})$, point length (HPL), shaft length (HSL), root length (HRL), aperture distance (HAD), proximal shaft width (HPSW), hamulus inner angle (HIA); ventral bar (VB): total length (VBTL), total width (VBTW), process-to-mid length (VBPML), median length (VBML), process length (VBPL), membrane length (VBMBL); marginal hook (MH): total length (MHTL), shaft length (MHSHL), sickle length (MHSL), sickle proximal width (MHSPW), sickle distal width (MHSDW), sickle toe length (MHSTL), sickle aperture (MHAD). Five new morphometric variables are also described here: marginal hook $(\mathrm{MH})$ : instep height $(\mathrm{MHIH})$; hamulus $(\mathrm{H})$ : distal shaft width
(HDSW), inner curve length (HICL), aperture angle (HAA), point curve angle (HHPCA). The derivation of each measurement is presented in Figs. 1-4.

Statistical analysis. The cosine was taken to transform the data for the angle-based morphometrics (hamulus inner angle, hamulus aperture angle, hamulus point curve angle) to a linear function prior to analysis. The data were then analysed by univariate, non-parametric Kruskal-Wallis post hoc tests and by forward stepwise linear discriminant analyses using GraphPad InStat ver. 3.06 (GraphPad Software Inc., 1992-2003) and Statistica 6.0 (StatSoft, Inc., 1997), respectively.

The morphometric data were first analysed by univariate statistics to determine whether differences in single morphometric parameters could be used to separate specimens of populations. The data were subsequently analysed by a multivariate, discriminant analysis approach.

\section{RESULTS}

\section{Univariate statistics}

Table 1 shows the summary data for all the morphometric measurements made on the opisthaptoral hooks and ventral bars of Gyrodactylus salaris and G. thymalli populations analysed within this study. Table 2 details the significant results of the Kruskal-Wallis post hoc tests. The specimens of $G$. thymalli collected from the River Rena (Norway) and the River Test (UK) could be readily discriminated from the River Lierelva and River Rauma populations of $G$. salaris. All four populations of Gyrodactylus could be discriminated on the basis of differences in ten morphometric parameters (hamulus: total length, point length, distal shaft width, inner curve length, point curve angle; marginal hook: total length, shaft length, sickle length, aperture distance and instep height). The Norwegian $G$. thymalli population but not the UK population could also be discriminated from both $G$. salaris populations by differences in their ventral bar median lengths, their marginal hook toe lengths and proximal widths of the sickle. The unique morphometric feature that permitted discrimination of the River Test $G$. thymalli population from the two $G$. salaris populations was the hamulus proximal shaft width. The $G$. salaris sample from the River Rauma could also be discriminated from both $G$. thymalli populations by differences in their hamulus root lengths, the size of the hamulus aperture angle and hamulus inner angle and by differences in their ventral bar process-to-mid lengths. The number of morphometric variables permitting differentiation between the two $G$. salaris populations was much lower. Only four univariate parameters gave differences, i.e. hamulus: total length, root length, inner curve length; ventral bar: process length. Differentiation between the two $G$. thymalli populations was much better with significant differences between 12 of the measured parameters.

All five newly described characters (hamulus: distal shaft width, inner curve length, aperture angle, point 

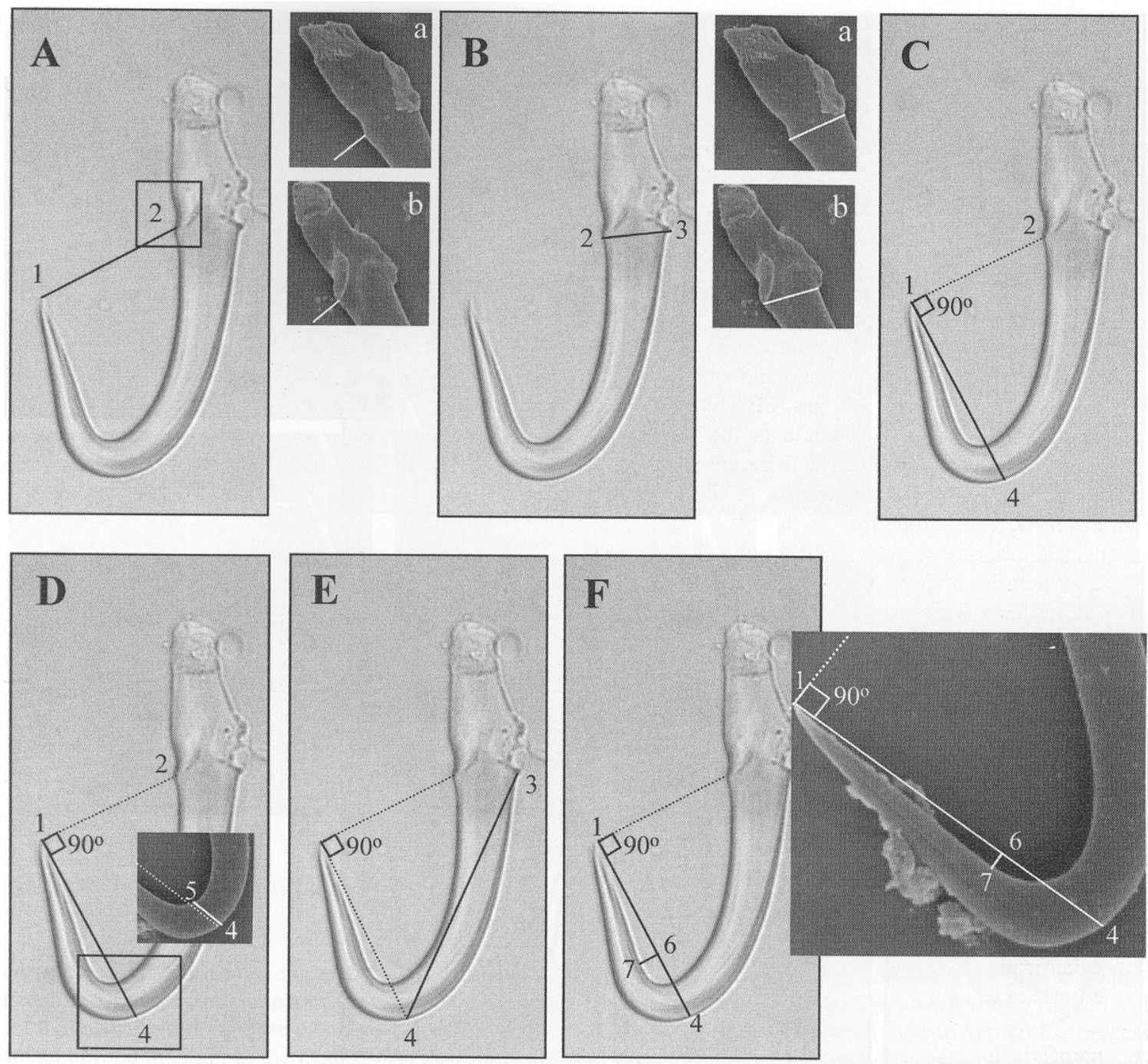

Fig. 1 A-F. Light micrographs of the hamuli $(\mathrm{H})$ from Gyrodactylus thymalli Žitňan, 1960 from Thymallus thymallus L. and scanning electron micrographs of the hamuli of G. salaris Malmberg, 1957 from Salmo salar L. (inserts) illustrating the morphometric parameters measured. A. Hamulus aperture distance (HAD): The distance between the hamulus point tip (1) and the lower edge of the ventral bar articulation point on the hamulus (2). The insets show the position of point (2) on the outer (a) and inner (b) flanks of the hamulus. B. Hamulus proximal shaft width (HPSW): The distance between the lower edge of the ventral bar articulation point on the hamulus (2) and the lower edge of the dorsal bar attachment point on the hamulus (3). The insets show the position of each point on the outer (a) and inner (b) flanks of each hamulus. C. Hamulus point length (HPL): A $90^{\circ}$ vector is dropped from the line (1-2), at the hamulus point, to a point on the outer edge of the hamulus (4). The hamulus point length is the distance between points 1 and 4. D. Hamulus distal shaft width (HDSW): Defined as the width of the hamulus at the point where the vector describing the hamulus point length crosses the hamulus. The inset shows this measurement as a solid line (4-5). E. Hamulus shaft length (HSL): The distance between the base of the hamulus point as defined by point (4) and the lower edge of the dorsal bar attachment point (3). F. Hamulus inner curve length (HICL): A line is drawn from the hamulus point tip (1) to its base (4) and a $90^{\circ}$ vector is dropped from this line to the zenith of the inner curve of the hamulus (6-7).

curve angle; marginal hook: instep height) gave significant differences between the four populations of Gyrodactylus under study. The hamulus inner curve length was particularly useful permitting some discrimination between both populations of $G$. salaris and both populations of $G$. thymalli in addition to the various crosscomparisons of each population. In this analysis, only the marginal hook sickle distal width was apparently redundant in the discrimination of these populations.

\section{Discriminant analysis}

Table 3 presents the model generated by the linear forward stepwise discriminant analysis, which used 18 of the 25 original variables given in Table 1 . A chisquare test applied to successively removed roots shows that only the first three roots are required to confidently separate the gyrodactylid populations (Table 3). The first three roots accounting for $61.4 \%, 96.6 \%$ and $100 \%$ of the total variation between specimens respectively, 

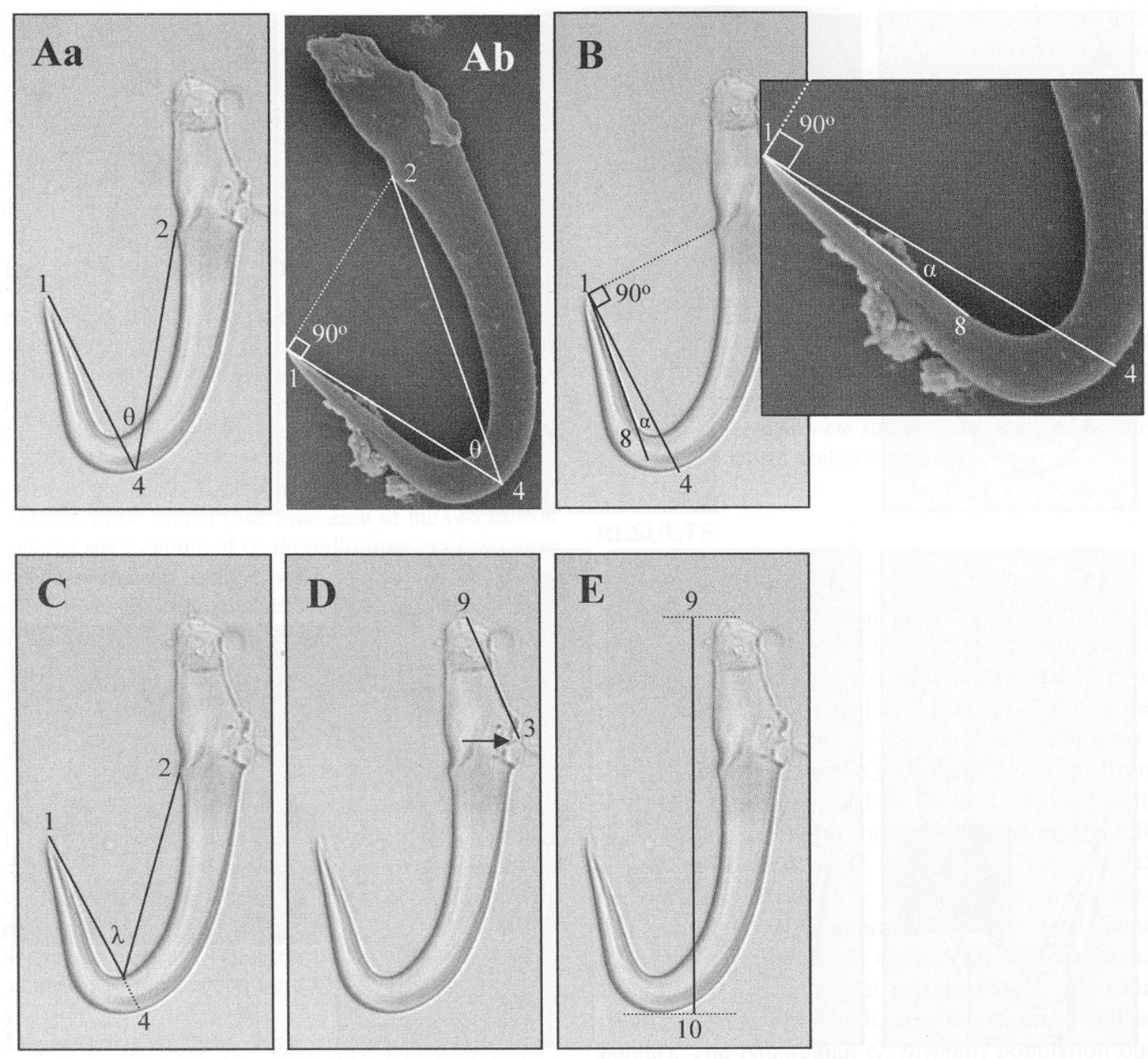

Fig. 2 A-E. Light micrographs of the hamuli $(\mathrm{H})$ from Gyrodactylus thymalli Žitñan, 1960 from Thymallus thymallus L. and scanning electron micrographs of the hamuli of G. salaris Malmberg, 1957 from Salmo salar L. illustrating the morphometric parameters measured. A. Hamulus aperture angle (HAA): The angle $\theta$ between the hamulus point tip (1), through its base (4) and the lower edge of the ventral bar articulation point on the hamulus (2). B. Hamulus point curve angle (HPCA): Defined as the angle $\alpha$ between the hamulus point tip (1), its blade (8) and the vector describing its length and base (4). C. Inner hamulus aperture angle (HIA): The angle $\lambda$ between the hamulus point tip (1), through the vector describing its length to the inner curve of the hamulus (4) and the lower edge of the ventral bar articulation point on the hamulus (2). D. Hamulus root length (HRL): The distance from the mid-point of the dorsal bar attachment point (3) (arrow) to the mid-point of the distal edge of the hamulus (9). E. Hamulus total length (HTL): The distance from the nadir of the hamulus curve (10) to the very distal point of the hamulus root (9).

with, in descending order, the hamulus shaft length, the hamulus total length and the marginal hook instep height contributing the most to the overall discrimination of specimens. When the canonical scores from the linear discriminant analysis are plotted and viewed in the first two planes (Fig. 5), it can be seen that the $G$. salaris and G. thymalli specimens are clearly separated, as are the two G. thymalli populations. When the data are viewed in a second projection (Root $3 v s$ Root 1) (Fig. 6), it is possible to see a level of separation between the majority of specimens belonging to the two G. salaris populations. When the Mahalanobis distances are calculated for the top 18 variables, the analysis gave an overall correct classification efficiency of $97.7 \%$ (see Table 4) with all G. thymalli specimens being correctly assigned to their respective $G$. thymalli populations. The only misclassifications were three specimens of $G$. salaris from River Lierelva, which were incorrectly assigned to the Rauma population. From the discriminant analysis, the hamulus shaft length was taken as the first 

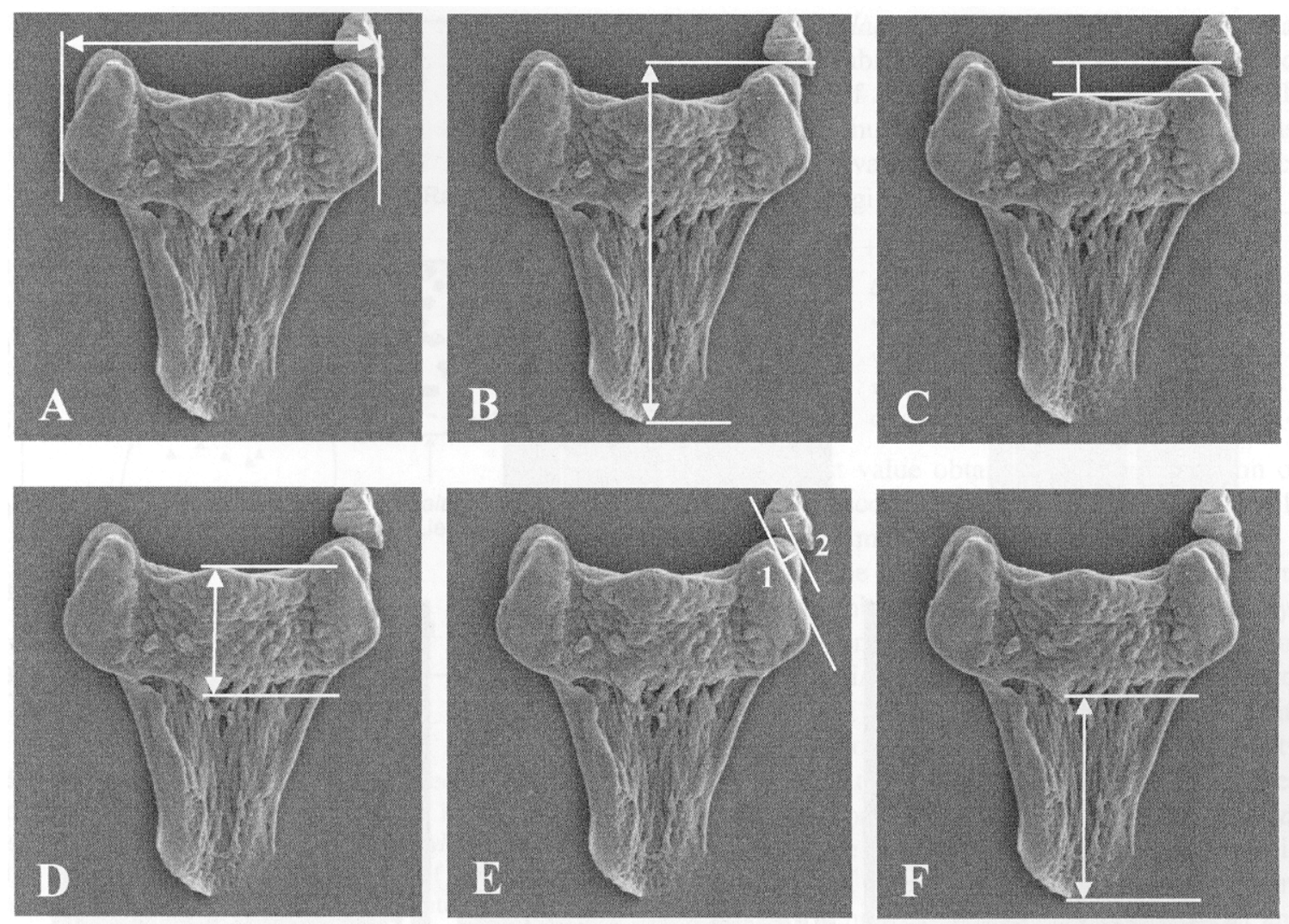

Fig. 3 A-F. Scanning electron micrographs of the ventral bar (VB) from Gyrodactylus salaris Malmberg, 1957 from Salmo salar L. illustrating the morphometric parameters measured. A. Ventral bar total width (VBTW): The total width in figure (A) is the width of the median portion of the ventral bar; whereas in figure (B) it is the distance between the two ventral bar processes as they extend beyond the limit of the median bar. B. Ventral bar total length (VBTL): The distance between the top of the median bar and the distal edge of the ventral bar membrane as in figure (A) (should the ventral bar lack processes) or it is defined as the distance from the top of the ventral bar processes to the distal edge of the ventral bar membrane as in figure (B). C. Ventral bar process-to-mid length (VBPML): For ventral bars lacking processes (A), this is the perpendicular distance (1) from the top of the distal extremity of the median portion to a parallel line marking its mid-point. For species possessing ventral bar processes (B), the process-to-mid length distance is the perpendicular distance between a line marking the distal edge of the processes to a parallel line marking the top of the median portion of the ventral bar. D. Ventral bar median length (VBML): The perpendicular distance from the top of the median portion of the ventral bar to its base, where it joins with the ventral bar membrane. E. Ventral bar process length (VBPL): The perpendicular distance from the end of the median portion of the ventral bar (1) to the distal point of the ventral bar process (2). Some species such as that shown in (A) have no processes and thus no value for this parameter. F. Ventral bar membrane length (VBMBL): The distance between the lower edge of the median bar and the distal edge of the ventral bar membrane.

step in the discriminant analysis (see Tables 3 and 7). When this variable alone was considered (Tables 5 and 7 ), it was possible to obtain an overall correct classification efficiency of $66.67 \%$, but with misclassifications between all populations. From the analyses it was determined that the total hamulus length contributes a further $17 \%$ to the total discrimination of specimens and the marginal hook sickle length an extra 7\%. From variables listed in Table 3, the first six variables are needed for the correct classification of $G$. salaris specimens as $G$. salaris and the first ten variables for correct classification of $G$. thymalli specimens.
From the model, the principal ten elements in decreasing order of their contribution to the separation of specimens in the analysis as determined by their partial lambda scores (see Table 3) were the hamulus shaft length (HSL), hamulus total length (HTL), marginal hook instep height (MHIH), ventral bar process length (VBPL), hamulus aperture distance (HAD), hamulus distal shaft width (HDSW), hamulus root length (HRL), marginal hook total length (MHTL), marginal hook sickle distal width (MHSDW) and the ventral bar total length (VBTL). The classification functions for each of the morphometric variables for specimens of each popu- 

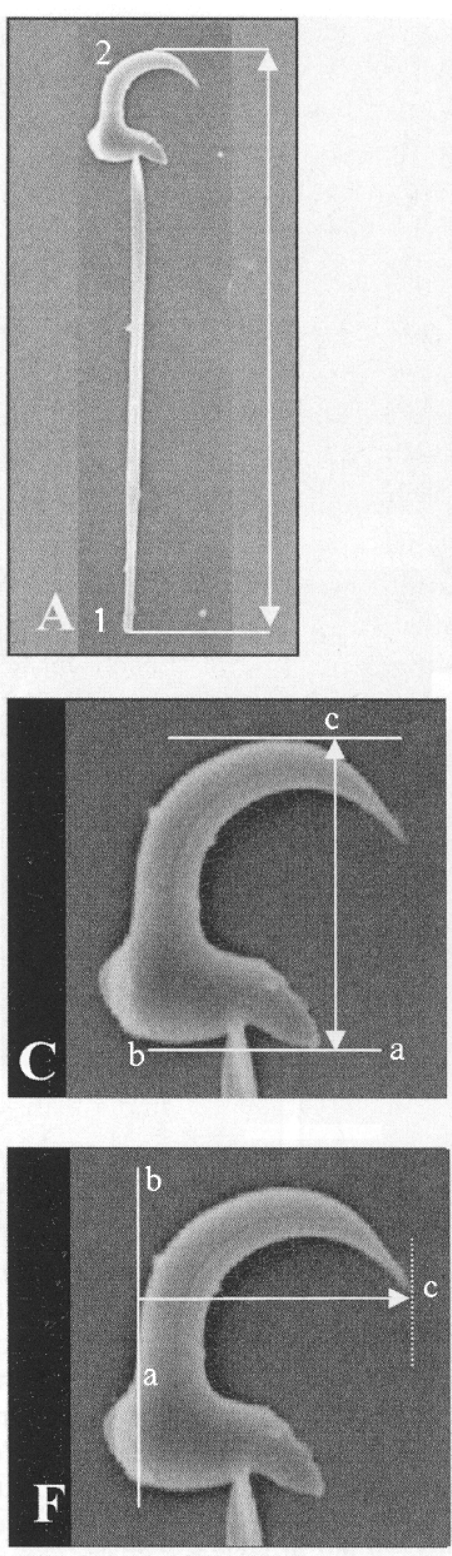
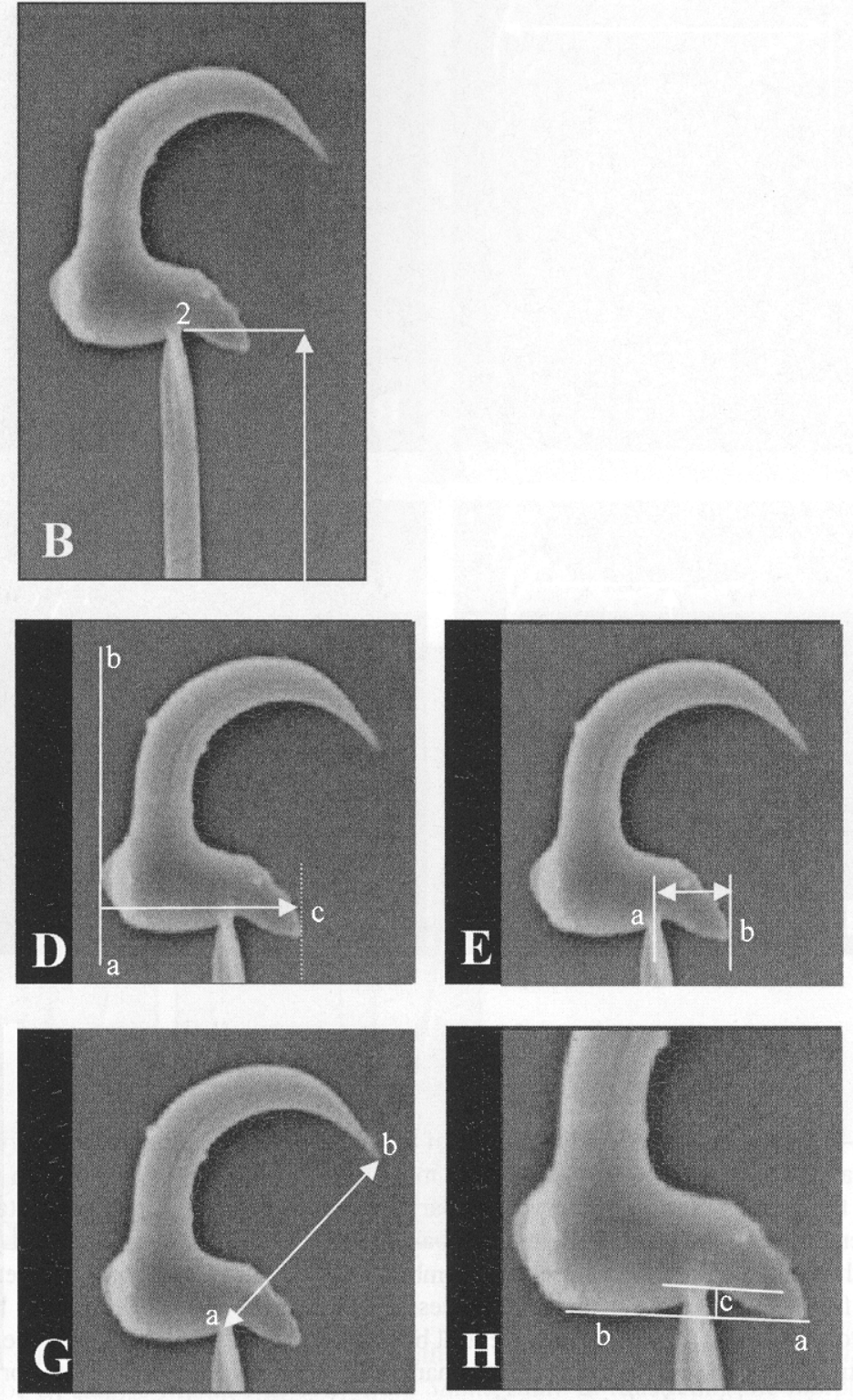

Fig. 4 A-H. A light micrograph of a marginal hook (MH) of Gyrodactylus salaris Malmberg, 1957 from Salmo salar L. and scanning electron micrographs of the marginal hooks of $G$. salaris illustrating the morphometric parameters measured. A. Marginal hook total length (MHTL): The distance between the distal point of the shaft (1) and the distal point of the marginal hook sickle (2). B. Marginal hook shaft length (MHSHL): The distance between the distal point of the shaft (1) and the connection the marginal hook shaft makes with the marginal hook sickle (2). C. Marginal hook sickle length (MHSL): A parallel line from the lowest part of the base of the sickle $(\mathrm{a}-\mathrm{b})$ to the most distal point $(\mathrm{c})$. D. Marginal hook sickle proximal width (MHSPW): The perpendicular distance from a line drawn parallel to the heel $(\mathrm{a}-\mathrm{b})$ to the most distal point of the toe (c). E. Marginal hook toe length (MHSTL): The distance from the point where the marginal hook shaft attaches to the marginal hook sickle (a) to the distal point of the toe (b). F. Marginal hook sickle distal width (MHSDW): The distance between a line parallel with the shaft $(a-b)$ to the marginal sickle point tip (c). G. Marginal hook aperture (MHAD): This aperture is defined as the distance between the point where the marginal hook shaft joins the sickle (a) and the tip of the marginal hook sickle point (b). $\mathbf{H}$. Marginal hook instep/arch height (MHIH): The distance between a line (a-b) that touches the toe and heel of the sickle to the top of the arch at a point where the marginal hook shaft joins onto the sickle (c). 


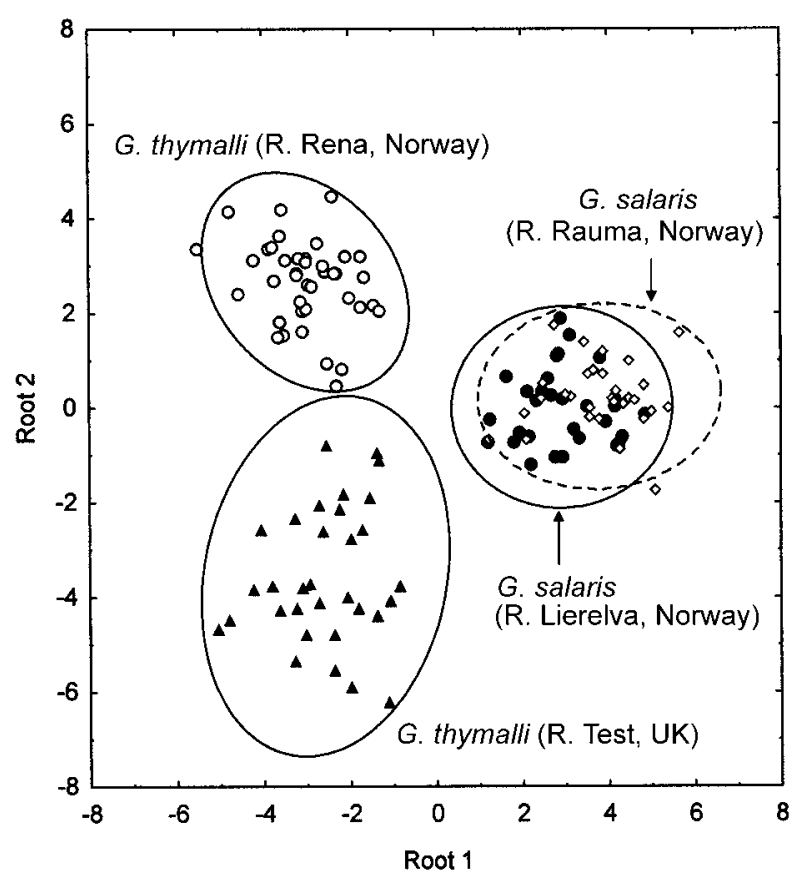

Fig. 5. Plot of the morphometric data based on the 18 best variables selected by a forward discriminant analysis. The plot shows the distribution of the four Gyrodactylus populations in the first two planes (Root $1 v s$ Root 2) of the discriminant analysis. Ellipses are $95 \%$ confidence intervals about the mean. $\mathrm{R}$ - river.

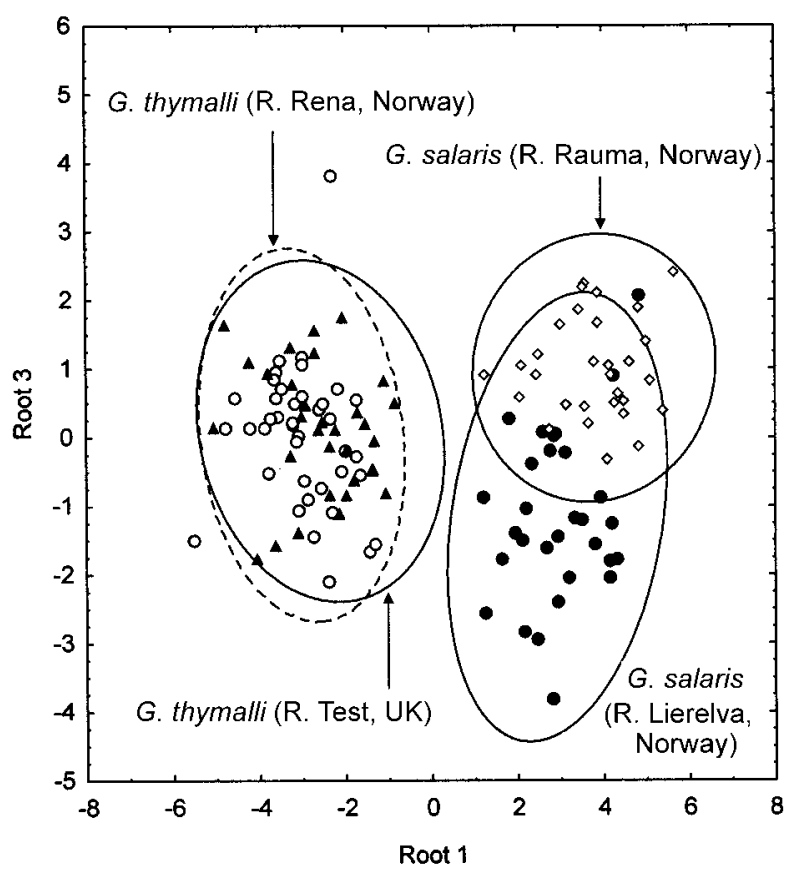

Fig. 6. Plot of the light morphometric data based on the 18 best variables selected by a forward discriminant analysis. The plot shows the distribution of the four Gyrodactylus populations in a second projection (Root $1 v s$ Root 3) of the discriminant analysis. Ellipses are 95\% confidence intervals about the mean. $\mathrm{R}$ - river. lation of Gyrodactylus used in the discriminant analysis are given in Table 6. Based on these data and model, a gyrodactylid of unknown location and host could be classified by multiplying the value of each measured morphometric variable with its respective classification function value given in Table 6 , as follows:

$$
\mathrm{S}_{\mathrm{i}}=\mathrm{C}_{\mathrm{i}}+\left(\mathrm{W}_{\mathrm{i} 1} \times \mathrm{X}_{1}\right)+\left(\mathrm{W}_{\mathrm{i} 2} \times \mathrm{X}_{2}\right)+\ldots \ldots
$$

where: $\mathrm{C}_{\mathrm{i}}=$ constant for the ${ }_{\mathrm{i}}$ th group

$\mathrm{W}_{\mathrm{ij}}=$ weight for the ${ }_{\mathrm{j}}$ th variable

$\mathrm{X}_{\mathrm{i}}=$ value of the measured morphometric variable (in $\mu \mathrm{m}$ )

$\mathrm{S}_{\mathrm{i}}=$ classification score for the specimen

The largest value obtained after computation of the classification scores for each Gyrodactylus population determines the most likely origin of that specimen.

To determine the contribution of each variable to the overall discrimination of the species under study, the top variable (or first step) in each preceding run of the stepwise discriminant analysis was removed and the overall correct classification of specimens calculated (Table 7). Although there are misclassifications between individuals of the two $G$. salaris populations, the first misclassification of a $G$. thymalli specimen as $G$. salaris arises after the removal of the first five key variables (hamulus shaft length, hamulus point length, marginal hook sickle length, marginal hook instep height and the hamulus total length). For each round of analysis, the discriminant analysis uses an optimal number of variables and steps from the variables available to effect the best discrimination of the specimens.

When the data for the two species are considered separately and analysed as shown in Figs. 7 and 8, it can be seen that for $G$. thymalli only three variables are needed to separate the Norwegian River Rena population from the British River Test population to account for all the variation between the two (Fig. 7). For G. thymalli, the hamulus shaft length accounts for $95.8 \%$ of the total variation, the hamulus total length for a further $2.8 \%$ and the marginal hook total length for the remaining $1.4 \%$. Full discrimination between the two G. salaris populations was not possible, the first five variables accounting for only ca. $93.5 \%$ of the total variation between them (Fig. 8). Despite the subsequent addition of extra morphometric characters, the overall percentage of correct classification is reduced. While adding further characters improves the correct classification of specimens in one population, the data become over-fitted, and the overall percentage of correct classification falls.

\section{DISCUSSION}

Sequences of the cytochrome oxidase I provide a genetic framework for separating populations of Gyrodactylus salaris and G. thymalli (see Hansen et al. 2003, Meinilä et al. 2004) and the present study tested whether different populations of these species bearing different 


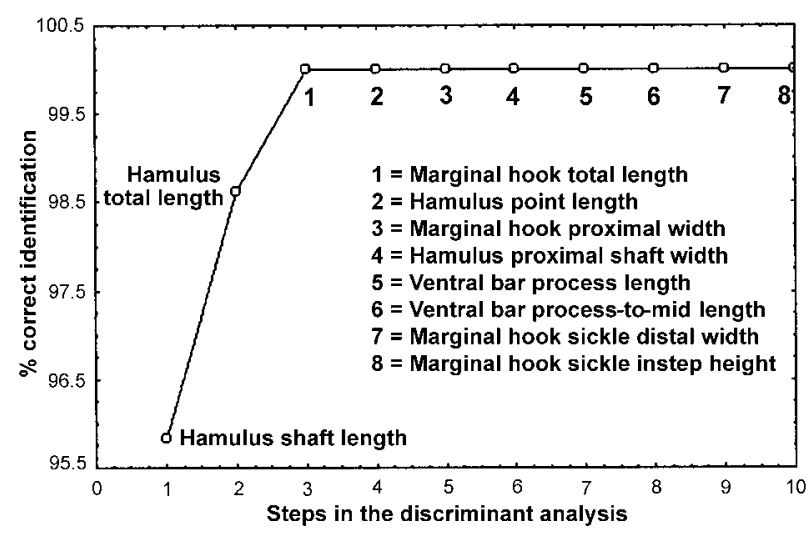

Fig. 7. Summary of the stepwise linear discriminant analysis for the two populations of G. thymalli (River Rena (Norway) versus River Test (UK)). The graph shows the contribution of each variable to the overall separation of the two G. thymalli populations.

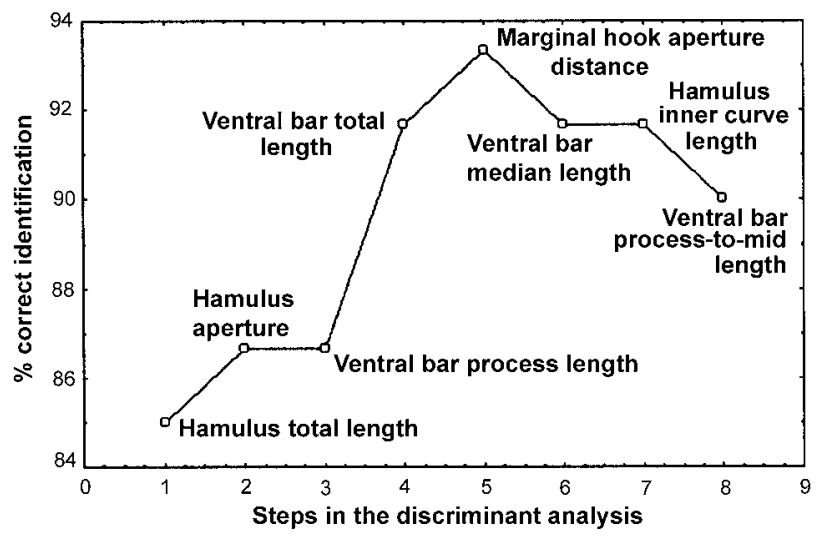

Fig. 8. Summary of the stepwise linear discriminant analysis for the two Norwegian populations of G. salaris (River Lierelva versus River Rauma). The graph shows the contribution of each variable to the overall separation of the two G. salaris populations.

mitochondrial haplotypes could be discriminated using morphometric methods. An earlier study by McHugh et al. (2000) demonstrated that G. salaris and G. thymalli could be separated to a high degree of accuracy $(98+\%)$ when statistical methods of classification (linear discriminant analysis and k-nearest neighbours) are applied to morphometric data. An extension of the linear discriminant analysis technique in the present study has permitted the discrimination of two laboratory-reared populations of $G$. salaris and two populations of $G$. thymalli, to a high degree of accuracy (ca. 97\%). When the current data were pooled for each species and analysed by linear discriminant analysis, there was complete discrimination of $G$. salaris (Rivers Lierelva \& Rauma) from G. thymalli (Rivers Rena \& Test). When the four populations were considered, then the only misclassifications included three specimens of $G$. salaris from the River Lierelva population, which were confused with specimens of $G$. salaris from the River Rauma population. All the specimens of $G$. thymalli from the River Test (UK) and the River Rena (Norway) and the G. salaris individuals from the River Rauma were correctly assigned. Separation of the two populations within a species was, therefore, possible. Differing environmental conditions, however, may account for the relative ease with which the two G. thymalli populations were separated. Whilst, the Norwegian River Rena population was maintained under standardized laboratory conditions, the specimens of $G$. thymalli from the River Test (UK) were taken directly from the river.

The application of image analysis to gyrodactylid morphology has facilitated the collection of complex parameters. Using digital calipers, accurate measurements can be taken on characters that have curved features. Five new morphological characters, one of the marginal hook and four of the hamulus, were described for G. salaris and G. thymalli and assessed in this study. The proximal part (or foot) of the marginal sickle is generally poorly described with few descriptive details pertaining to the size and shape of the heel and toe portions. Although Shinn et al. (2001) added the measurement of the toe to the list of morphometric characters, the degree to which the toe and/or the heel dropped away from the sickle base was not considered. The addition of the marginal hook instep height (MHIH) or arch height permits a basic numeric assessment of one further feature of the sickle. Future studies could consider the width of the heel taken as the perpendicular distance between a line parallel with the sickle shaft to the heel's most distal point. The sickle proximal part is commonly referred to as "narrow" or "robust", the utility of taking the depth of the sickle base might be considered. The depth would be the perpendicular distance between two parallel lines, one joining the nadirs of the toe and heel and the second lying along the bridge or upper flat surface of the sickle base. In this study, the height of the marginal hook instep was valuable in discriminating both populations of $G$. salaris from both populations of $G$. thymalli in the univariate statistical tests (Table 2). The instep height also made the third largest contribution to the overall discrimination of all populations in the discriminant analysis (Table 3).

The four new characters described for the hamulus are the distal shaft width (HDSW), the inner curve length (HICL), the aperture angle (HAA) and the point curve angle (HPCA). Shinn et al. (2001) demonstrated the value of the newly described hamulus inner angle (HIA) in discriminating G. salaris from other Gyrodactylus species parasitizing British salmonids. The hamulus angle, however, describes only the inner curve of the hamulus. Therefore, we expected the measurement of the external curve (HAA) and its width 
Table 1. Summary of the morphometric measurements for the two species of Gyrodactylus analysed in this study. Each measured feature is given as micrometres ( $\mu \mathrm{m}$ ) followed by the standard deviation and the range (in parentheses). $\mathrm{R}$ - river; $\mathrm{n}-$ number of specimens measured.

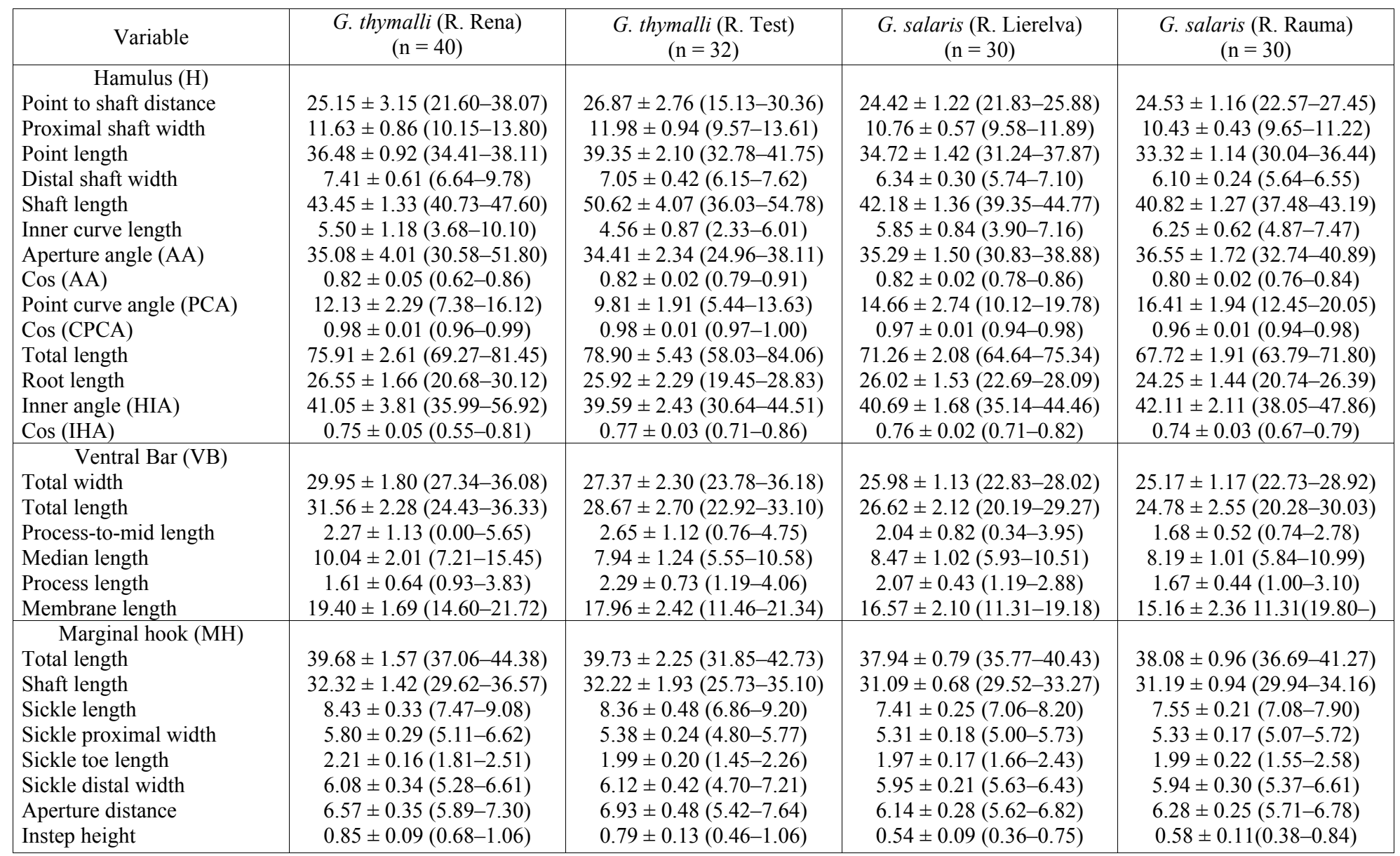


Table 2. Kruskal-Wallis post hoc test for each morphometric variable and for each population of Gyrodactylus from the rivers: Test, Lierelva and Rauma showing only those variables that were significant $(\mathrm{P}<0.05)$ between populations. The mean rank difference as determined by Kruskal-Wallis is given for each variable in parentheses. Abbreviations: see Figs. 1-4 and the "Morphometric analysis" section of the Materials and methods.

\begin{tabular}{|c|c|c|c|}
\hline & G. thymalli (Test) & G. salaris (Lierelva) & G. salaris (Rauma) \\
\hline G. thymalli (Rena) & $\begin{array}{l}\text { HAD }(-47.81) \\
\text { HPL }(-30.50) \\
\text { HSL }(-37.24) \\
\text { HICL }(-29.05) \\
\text { HPCA }(-27.64) \\
\text { VBTW }(39.68) \\
\text { VBTL }(31.84) \\
\text { VBML }(43.74) \\
\text { VBPL }(-44.51) \\
\text { MHSPW }(45.69) \\
\text { MHSTL }(38.13) \\
\text { MHAD }(-28.03)\end{array}$ & $\begin{array}{l}\text { HTL (36.52) } \\
\text { HPL }(32.42) \\
\text { HDSW }(58.90) \\
\text { HPSW }(35.61) \\
\text { HICL }(26.31) \\
\text { HPCA }(28.51) \\
\text { VBTW }(59.70) \\
\text { VBTL }(56.30) \\
\text { VBML }(29.36) \\
\text { VBPL }(-40.88) \\
\text { VBMBL }(44.38) \\
\text { MHSHL }(36.79) \\
\text { MHSL }(68.67) \\
\text { MHSTL }(45.25) \\
\text { MHSPW }(57.52) \\
\text { MHAD }(40.55) \\
\text { MHIH }(70.92) \\
\text { MHTL (43.97) }\end{array}$ & $\begin{array}{l}\text { HTL (63.38) } \\
\text { HPL }(55.94) \\
\text { HRL }(49.87) \\
\text { HDSW }(75.27) \\
\text { HSL }(46.31) \\
\text { HPSW }(51.70) \\
\text { HICL }(55.43) \\
\text { HAA }(43.40) \\
\text { HPCA }(50.14) \\
\text { HIA }(28.88) \\
\text { VBTW (78.15) } \\
\text { VBTL }(74.24) \\
\text { VBPML }(-10.41) \\
\text { VBML }(41.51) \\
\text { VBMBL }(60.53) \\
\text { MHSHL }(33.59) \\
\text { MHSL }(56.97) \\
\text { MHSTL (42.40) } \\
\text { MHSPW (55.60) } \\
\text { MHAD (27.57) } \\
\text { MHIH (61.92) } \\
\text { MHTL (40.89) }\end{array}$ \\
\hline G. thymalli (Test) & & $\begin{array}{l}\text { HAD }(-49.76) \\
\text { HPSW }(-47.08) \\
\text { HPL }(-62.92) \\
\text { HDSW }(-45.32) \\
\text { HSL }(-59.30) \\
\text { HICL }(55.36) \\
\text { HTL }(-58.60) \\
\text { HPCA }(-56.15) \\
\text { MHTL }(-50.77) \\
\text { MHSHL }(-40.53) \\
\text { MHSL }(-64.35) \\
\text { MHAD }(-68.59) \\
\text { MHIH }(-55.06)\end{array}$ & $\begin{array}{l}\text { HAD }(-50.06) \\
\text { HPSW }(-63.17) \\
\text { HPL }(-86.44) \\
\text { HDSW }(-61.69) \\
\text { HSL }(-83.55) \\
\text { HICL }(84.48) \\
\text { HTL }(-85.47) \\
\text { HRL }(-40.50) \\
\text { HPCA }(-77.78) \\
\text { HAA }(-39.37) \\
\text { HIA }(-47.32) \\
\text { VBTW }(38.47) \\
\text { VBTL }(-42.40) \\
\text { VBPML }(-38.11) \\
\text { VBPL }(-35.13) \\
\text { VBMBL }(-39.35) \\
\text { MHTL }(-47.69) \\
\text { MHSHL }(-37.33) \\
\text { MHSL }(-52.65) \\
\text { MHAD }(-55.60) \\
\text { MHIH }(-46.06)\end{array}$ \\
\hline G. salaris (Lierelva) & & & $\begin{array}{l}\text { HTL }(26.87) \\
\text { HRL }(38.88) \\
\text { HICL }(-29.11) \\
\text { VBPL }(31.50)\end{array}$ \\
\hline
\end{tabular}

(HDSW) through the same points to be more informative rather than stating that the hamulus is "thin" or "robust". The point of the hamulus is not always straight, therefore, the introduction of the hamulus point curve angle attempted to provide a quantitative description of the hamulus in this region. All four parameters discriminated the four populations of Gyrodactylus under study. The distal shaft width (HDSW), the inner curve length (HICL) and the point curve angle (HPCA) were found to give significant differences in the univariate pair-wise comparisons (Table 2). The hamulus aperture angle (HAA) was useful in discriminating the specimens of $G$. salaris from the River Rauma from both populations of $G$. thymalli (Table 2). Only four characters discriminated the two $G$. salaris populations (HTL, HRL, VBPL and HICL), the latter representing 
Table 3. Chi-square tests with successive roots removed and standardized coefficients for the canonical variables of the top 18 morphometric variables selected by the linear stepwise discriminant analysis, the eigenvalues and the proportion of the variance explained by the first three roots. The variables with the smallest partial lambda figures contribute the most to the overall discrimination of the analysed specimens.

\begin{tabular}{|c|c|c|c|c|c|c|c|}
\hline Roots removed & Eigenvalue & Chi-Sqr. & df & p-level & & & \\
\hline 0 & 10.236 & 575.156 & 54 & 0.0000001 & & & \\
\hline 1 & 5.977 & 284.858 & 34 & 0.0000001 & & & \\
\hline 2 & 0.561 & 53.481 & 16 & 0.000006 & & & \\
\hline Variable & & $\begin{array}{l}\text { Wilks' } \\
\text { lambda }^{1}\end{array}$ & $\begin{array}{c}\text { Partial } \\
\text { lambda }\end{array}$ & p-level & Root 1 & Root 2 & Root 3 \\
\hline Hamulus shaft length & & 0.0170 & 0.4872 & 0.0000 & -0.381 & -1.871 & -0.470 \\
\hline Hamulus total length & & 0.0104 & 0.8002 & 0.0000 & -0.570 & 0.749 & 1.225 \\
\hline MH instep height & & 0.0102 & 0.8131 & 0.0000 & -0.432 & 0.225 & -0.408 \\
\hline VB process length & & 0.0098 & 0.8495 & 0.0004 & 0.138 & -0.366 & 0.429 \\
\hline Hamulus aperture distance & & 0.0097 & 0.8507 & 0.0004 & 0.501 & 0.212 & -0.515 \\
\hline Hamulus distal shaft width* & & 0.0096 & 0.8624 & 0.0009 & -0.535 & 0.154 & 0.149 \\
\hline Hamulus root length & & 0.0093 & 0.8934 & 0.0057 & 0.465 & -0.006 & 0.283 \\
\hline MH total length & & 0.0092 & 0.8971 & 0.0070 & 0.427 & 0.289 & -0.083 \\
\hline MH sickle distal width & & 0.0090 & 0.9177 & 0.0226 & 0.347 & -0.016 & 0.132 \\
\hline VB total length** & & 0.0090 & 0.9250 & 0.0338 & -0.229 & 0.220 & -0.263 \\
\hline Hamulus inner curve length & & 0.0090 & 0.9260 & 0.0355 & 1.165 & 1.449 & 0.541 \\
\hline VB membrane length & & 0.0089 & 0.9338 & 0.0540 & -0.253 & 0.130 & 0.033 \\
\hline MH sickle length & & 0.0089 & 0.9361 & 0.0613 & -0.398 & 0.012 & -0.171 \\
\hline Hamulus point curve angl & & 0.0088 & 0.9437 & 0.0913 & 0.593 & 1.472 & 0.724 \\
\hline Hamulus proximal shaft width & & 0.0086 & 0.9631 & 0.2411 & 0.175 & 0.223 & -0.029 \\
\hline MH sickle proximal width & & 0.0086 & 0.9644 & 0.2574 & -0.145 & 0.178 & -0.002 \\
\hline VB process-to-mid length & & 0.0086 & 0.9660 & 0.2768 & -0.059 & 0.207 & 0.046 \\
\hline MH aperture distance & & 0.0085 & 0.9704 & 0.3401 & -0.034 & -0.053 & -0.366 \\
\hline Eigenvalue & & & & & 10.236 & 5.877 & 0.561 \\
\hline Cumulative proportion & & & & & 0.614 & 0.966 & 1.000 \\
\hline
\end{tabular}

${ }^{1}$ The following parameters are defined by Statistica as: Wilks' lambda is given as "the ratio of the determinant of the within-groups variance/covariance matrix divided by the determinant of the total variance/covariance matrix". Partial lambda is "the ratio of Wilks' lambda after adding the respective variable over the Wilks' lambda before adding the variable".

*Once this variable has been removed then specimens of $G$. salaris begin to be misclassified as $G$. thymalli, i.e. the first 6 variables are needed for the correct classification of $G$. salaris specimens as $G$. salaris.

**Once this variable has been removed then specimens of $G$. thymalli begin to be misclassified as G. salaris, i.e. the first 10 variables are needed for the correct classification of $G$. thymalli specimens.

one of the newly described morphometric variables (Table 2). This latter measurement and those made for the hamulus point curve angle (HPCA), were useful in discriminating the two populations of $G$. thymalli from each other. Three (HICL, HDSW, HPCA) of the four variables were among the top 18 variables upon which the discriminant analysis was based, confirming their value. Out of the morphometric parameters measured and assessed, only the marginal hook sickle distal width (MHSDW) did not contribute to the discrimination of the specimens of the populations analysed in this study. This latter determination was also confirmed by the discriminant analysis (Table 7) where the marginal hook sickle distal width is the last parameter to be used in the stepwise model.

When the two G. salaris populations were subjected to univariate analysis, only four morphometric characters were significantly different between the two populations. Similarly, complete discrimination between the two populations using discriminant analysis was impossible. Nevertheless, the level of discrimination that was observed between the two G. salaris populations is encouraging, although much lower than that observed between the two $G$. thymalli populations. The $G$. salaris populations were first of all separated on the basis of differences in the size of their hamuli and ventral bars rather than their marginal hooks which are generally regarded as the key taxonomic structure.

In the discrimination of the two $G$. thymalli populations (Figure 7), the three informative characters were measurements that had been used previously (HSL, HTL, MHTL), whereas those that were useful in separating the two G. salaris populations (Fig. 8) were a mixture of previously used (HTL, VBPL, VBTL) and the newly described parameters (HAD, MHAD) (this study and Shinn et al. 2001). Although the morphological form of the marginal hook is generally regarded as the key taxonomic criterion in the discrimination of species (Malmberg 1970), it is interesting to note that the hamuli are the most informative structures in this 
Table 4. Classification efficiency of each Gyrodactylus population from the rivers Rena, Test, Lierelva and Rauma using the top 18 out of 25 morphometric variables selected by the linear stepwise discriminant analysis as determined by Mahalanobis distances.

True Class

\begin{tabular}{|l|c|c|c|c|}
\hline & $\begin{array}{c}\text { G. thymalli (Rena) } \\
(\mathrm{n}=40) \\
\mathrm{p}=0.30303\end{array}$ & $\begin{array}{c}\text { G. thymalli (Test) } \\
(\mathrm{n}=32) \\
\mathrm{p}=0.24242\end{array}$ & $\begin{array}{c}\text { G. salaris (Lierelva) } \\
(\mathrm{n}=30) \\
\mathrm{p}=0.22727\end{array}$ & $\begin{array}{c}\text { G. salaris (Rauma) } \\
(\mathrm{n}=30) \\
\mathrm{p}=0.22727\end{array}$ \\
\hline G. thymalli (Rena) & 40 & 0 & 0 & 0 \\
G. thymalli (Test) & 0 & 32 & 0 & 0 \\
G. salaris (Lierelva) & 0 & 0 & 27 & 3 \\
G. salaris (Rauma) & 0 & 0 & 0 & 30 \\
\hline Total & 40 & 32 & 27 & 33 \\
Percent correct class & 100 & 100 & 90 & 100 \\
\hline
\end{tabular}

Overall correct classification efficiency $=97.73 \%$.

Table 5. Classification efficiency of each Gyrodactylus population from the rivers Rena, Test, Lierelva and Rauma using only the hamulus shaft length, selected as the first variable in the linear stepwise discriminant analysis.

True Class

\begin{tabular}{|l|c|c|c|c|}
\hline & $\begin{array}{c}\text { G. thymalli } \text { (Rena) } \\
(\mathrm{n}=40) \\
\mathrm{p}=0.30303\end{array}$ & $\begin{array}{c}\text { G. thymalli } \text { (Test) } \\
(\mathrm{n}=32) \\
\mathrm{p}=0.24242\end{array}$ & $\begin{array}{c}\text { G. salaris (Lierelva) } \\
(\mathrm{n}=30) \\
\mathrm{p}=0.22727\end{array}$ & $\begin{array}{c}\text { G. salaris (Rauma) } \\
(\mathrm{n}=30) \\
\mathrm{p}=0.22727\end{array}$ \\
\hline G. thymalli (Rena) & 37 & 1 & 0 & 2 \\
G. thymalli (Test) & 0 & 30 & 0 & 2 \\
G. salaris (Lierelva) & 22 & 0 & 1 & 8 \\
G. salaris (Rauma) & 8 & 0 & 0 & 21 \\
\hline Total & 67 & 31 & 1 & 33 \\
Percent correct class & 92.5 & 93.8 & 0.0 & 70.0 \\
\hline
\end{tabular}

Overall correct classification efficiency $=66.67 \%$.

Table 6. Classification functions for the discrimination of four populations of Gyrodactylus parasitizing salmonids from the rivers Rena, Lierelva, Rauma, Norway and the River Test, UK. The identification of a gyrodactylid or its discrimination from another Gyrodactylus population is given by the systematic use of the values in the equation Constant + (hamulus shaft length $\times$ value for first population of Gyrodactylus $)+$ (hamulus total length $\times$ value for first population of Gyrodactylus $)+(\mathrm{MH}$ sickle length $\times$ value for first population of Gyrodactylus $)+\ldots$. etc. For example for G. thymalli $($ Rena $)=-257981.80+($ measured value (in $\mu \mathrm{m}$ ) for the hamulus shaft length on a specimen of $G$. thymalli (Rena) $\times-114.07)+($ measured value (in $\mu \mathrm{m})$ for the hamulus total length on a specimen of $G$. thymalli $($ Rena $) \times-18.28)+\ldots$ etc.

\begin{tabular}{|l|c|c|c|c|}
\hline Variable & $\begin{array}{c}\text { G. thymalli (Rena) } \\
\mathrm{p}=0.30303\end{array}$ & $\begin{array}{c}\text { G. salaris (Lierelva) } \\
\mathrm{p}=0.22727\end{array}$ & $\begin{array}{c}\text { G. salaris (Rauma) } \\
\mathrm{p}=0.22727\end{array}$ & $\begin{array}{c}\text { G. thymalli (Test) } \\
\mathrm{p}=0.24242\end{array}$ \\
\hline Hamulus shaft length & -114.07 & -112.70 & -112.51 & -108.74 \\
Hamulus total length & -18.28 & -19.52 & -20.45 & -19.70 \\
MH sickle length & -680.29 & -687.75 & -687.71 & -680.09 \\
Hamulus inner curve length & 2050.71 & 2051.92 & 2051.95 & 2046.32 \\
MH instep height & 1831.24 & 1796.50 & 1801.52 & 1819.00 \\
MH total length & 4.92 & 5.85 & 6.25 & 3.60 \\
VB process length & 334.67 & 338.90 & 337.42 & 338.64 \\
VB total width & -43.14 & -44.51 & -44.27 & -43.92 \\
Hamulus aperture distance & 110.18 & 110.84 & 111.52 & 109.52 \\
Hamulus root length & -125.43 & -123.73 & -123.84 & 361.77 \\
Hamulus distal shaft width & 363.66 & 355.96 & 354.15 & -91.68 \\
MH sickle distal width & -91.62 & -85.03 & -84.96 & 19.97 \\
VB membrane length & 20.32 & 19.47 & 19.34 & 508109.80 \\
Hamulus point curve angle & 509184.80 & 509140.30 & 509047.10 & 36.07 \\
MH sickle proximal width & 40.82 & 34.85 & 34.41 & 142.25 \\
Hamulus proximal shaft width & 144.28 & 144.62 & 144.96 & -3.56 \\
VB process-to-mid length & -2.17 & -3.15 & -3.29 & 129.91 \\
MH aperture distance & 128.86 & 127.52 & 129.69 & -256857.70 \\
Constant & -257981.80 & -257837.40 & -257728.10 & \\
\hline
\end{tabular}


Table 7. Sequential removal of variables from the original list of variables $(n=25)$ subjected to discriminant analysis. In each case the morphometric variable identified as the key variable in the first step in the previous round of analysis was removed and the analysis rerun. Linear stepwise discriminant analyses were repeated until all variables had been removed. For each round of analysis, the number of steps (or variables) included within analysis is given, together with Wilks' lambda ${ }^{1}$ and the corresponding $\mathrm{F}$ value ${ }^{1}$ and $\mathrm{P}$ level and the overall percentage of correctly classifying individuals to their correct population once that variable has been removed. The sole contribution of each morphometric variable, as a percentage, to the overall discrimination of the four populations is also given.

\begin{tabular}{|l|c|c|c|c|c|c|}
\hline Variable removed & $\begin{array}{c}\text { Steps in } \\
\text { the analysis }\end{array}$ & $\begin{array}{c}\text { Wilks' } \\
\text { lambda }\end{array}$ & F value & P level & $\begin{array}{c}\text { Overall \% } \\
\text { correct classific. }\end{array}$ & $\begin{array}{c}\text { Sole contrib. to } \\
\text { overall classific. }\end{array}$ \\
\hline No variables removed & 18 & 0.0083 & 24.533 & $<0.00001$ & 97.73 & - \\
Hamulus shaft length & 18 & 0.0129 & 20.267 & $<0.00001$ & 95.45 & 66.67 \\
Hamulus point length & 16 & 0.0143 & 22.247 & $<0.00001$ & 95.45 & 71.97 \\
MH sickle length & 15 & 0.0156 & 23.086 & $<0.00001$ & 95.45 & 59.09 \\
MH instep height & 16 & 0.0213 & 18.576 & $<0.00001$ & 93.18 & 48.48 \\
Hamulus total length* & 15 & 0.0265 & 18.056 & $<0.00001$ & 91.67 & 75.00 \\
Hamulus distal shaft width & 12 & 0.0349 & 20.337 & $<0.00001$ & 92.42 & 53.03 \\
VB total width & 14 & 0.0394 & 16.080 & $<0.00001$ & 92.42 & 63.64 \\
Hamulus inner curve length & 15 & 0.0441 & 14.021 & $<0.00001$ & 62.42 & 47.73 \\
VB total length & 13 & 0.0484 & 15.713 & $<0.00001$ & 90.91 & 53.03 \\
Hamulus point curve angle & 15 & 0.0560 & 12.359 & $<0.00001$ & 80.15 & 46.97 \\
MH sickle proximal width & 13 & 0.0640 & 13.390 & $<0.00001$ & 89.39 & 45.45 \\
MH aperture distance & 12 & 0.0726 & 13.754 & $<0.00001$ & 87.88 & 49.24 \\
Hamulus proximal shaft width & 11 & 0.0750 & 14.868 & $<0.00001$ & 87.12 & 50.00 \\
VB membrane length & 10 & 0.1010 & 13.808 & $<0.00001$ & 84.85 & 48.48 \\
VB median length & 10 & 0.1336 & 11.494 & $<0.00001$ & 81.06 & 40.91 \\
MH toe length & 9 & 0.1663 & 11.031 & $<0.00001$ & 78.03 & 38.64 \\
MH total length & 8 & 0.1900 & 11.321 & $<0.00001$ & 72.73 & 38.64 \\
VB process length & 7 & 0.2242 & 11.416 & $<0.00001$ & 74.24 & 40.15 \\
Hamulus root length & 6 & 0.2909 & 10.594 & $<0.00001$ & 68.18 & 39.39 \\
MH shaft length & 4 & 0.3490 & 13.478 & $<0.00001$ & 63.64 & 38.64 \\
Hamulus aperture distance & 3 & 0.7345 & 4.608 & $<0.00001$ & 39.39 & 44.70 \\
VB process-to-mid length & 2 & 0.8545 & 3.462 & $<0.00260$ & 29.55 & 34.85 \\
Hamulus inner aperture angle & 2 & 0.8733 & 2.966 & $<0.00810$ & 32.58 & 28.79 \\
Hamulus aperture angle & 1 & 0.9504 & 2.228 & $<0.08810$ & 32.58 & 29.55 \\
MH sickle distal width** & - & - & - & - & - & 32.58 \\
\hline
\end{tabular}

*After the removal of the variables at this point, specimens of $G$. thymalli begin to be misclassified.

**Once this variable has been removed then there are no further variables left for analysis.

${ }^{1}$ The following parameters are defined by Statistica as: Wilks' lambda is given as "the ratio of the determinant of the withingroups variance/covariance matrix divided by the determinant of the total variance/covariance matrix". $F$ value is " $F=[(n-q-$ $\mathrm{p}) /(\mathrm{q}-1)] \times[(1-$ partial lambda)/partial lambda $]$ where $\mathrm{n}=$ nos. of cases, $\mathrm{q}=$ nos. of groups, $\mathrm{p}=$ nos. of variables, partial lambda = ratio of Wilks' lambda after adding the respective variable over the Wilks' lambda before adding the variable".

study. The marginal hook, notably for the separation of the G. salaris populations, plays an arguably minor role.

The present study has shown that statistical classification of morphometric characters can separate populations of Gyrodactylus bearing different mitochondrial haplotypes. We conclude that despite large overlaps in the measurements of individual morphometric characters, the statistical classification of distance landmarks is a powerful tool in gyrodactylid taxonomy.

Acknowledgements. We thank K. Kvalsvik, Zoological Museum, Natural History Museums and Botanical Garden, Uni- versity of Oslo, Norway for help with preparations and keeping laboratory infections, J. Cable, Cardiff University, UK, for comments on an earlier version of the manuscript and $\mathrm{M}$. Longshaw, Weymouth Laboratory, CEFAS, UK for the collection and loan of G. thymalli specimens from the River Test. The work was funded by the Norwegian Research Council (Projects 145861/ 720 and 146515/420) and by DEFRA contract FC1145. A study visit by T.A. Bakke to Scotland was supported through an award from the European Union Access to Research Infrastructures (ARI) Action of the Improving Human Potential (IHP) Programme (contract HPRI-CT-199900106). 


\section{REFERENCES}

BAKKE T.A., HARRIS P.D., CABLE J. 2002: Host specificity dynamics: observations on gyrodactylid monogeneans. Int. J. Parasitol. 32: 281-308.

BUCHMANN K., LINDENSTRØM T., NIELSEN M.E., BRESCIANI J. 2000: Diagnostik og forekomst af ektoparasitinfeksjoner (Gyrodactylus spp.) hos danske laksefisk. Dan. Veterinaertidsskr. 83: 15-19.

ERGENS R. 1983: Gyrodactylus from Eurasian freshwater Salmonidae and Thymallidae. Folia Parasitol. 30: 15-26.

HANSEN H., BACHMANN L., BAKKE T.A. 2003: Mitochondrial DNA variation of Gyrodactylus spp. (Monogenea, Gyrodactylidae) populations infecting Atlantic salmon, grayling and rainbow trout in Norway and Sweden. Int. J. Parasitol. 33: 1471-1478.

JOHNSEN B.O., MØKKELGJERD P.I., JENSEN A.J. 1999: Parasitten Gyrodactylus salaris på laks i norske vassdrag, statusrapport ved inngangen til år 2000. NINA Oppdragsmelding 617: 1-129.

KOSKI P., MALMBERG G. 1995: Occurrence of Gyrodactylus (Monogenea) on salmon and rainbow trout in fish farms in Northern Finland. Bull. Scand. Soc. Parasitol. 5: $76-88$.

MALMBERG G. 1970: The excretory systems and the marginal hooks as a basis for the systematics of Gyrodactylus (Trematoda, Monogenea). Ark. Zool. 2: 1-235.

MALMBERG G., MALMBERG M. 1993: Species of Gyrodactylus (Platyhelminthes, Monogenea) on salmonids in Sweden. Fish. Res. 17: 59-68.

MATEJUSOVÁ I., GELNAR M., McBEATH A.J.A., COLLINS C.M., CUNNINGHAM C.O. 2001: Molecular markers for gyrodactylids (Gyrodactylidae: Monogenea) from five fish families (Teleostei). Int. J. Parasitol. 31: 738-745.

McHUGH E.S., SHINN A.P., KAY J.W. 2000: Discrimination of the notifiable pathogen Gyrodactylus salaris from G. thymalli (Monogenea) using statistical classifiers applied to morphometric data. Parasitology 121: 315-323.

MEINILÄ M., KUUSELA J., ZIETARA M.S., LUMME J. 2004: Initial steps of speciation by geographic isolation and host switch in salmonid pathogen Gyrodactylus salaris (Monogenea: Gyrodactylidae). Int. J. Parasitol. 34: 515-526.

MO T.A. 1991a: Seasonal variations of opisthaptoral hard parts of Gyrodactylus salaris Malmberg, 1957 (Mono- genea: Gyrodactylidae) on parr of Atlantic salmon (Salmo salar L.) in the River Batnfjordselva, Norway. Syst. Parasitol. 19: 231-240.

MO T.A. 1991b: Variations of opisthaptoral hard parts of Gyrodactylus salaris Malmberg, 1957 (Monogenea: Gyrodactylidae) on rainbow trout Oncorhynchus mykiss (Walbaum, 1792) in a fish farm, with comments on the spreading of the parasite in south-eastern Norway. Syst. Parasitol. 20: 1-9.

MO T.A. 1991c: Variations of opisthaptoral hard parts of Gyrodactylus salaris Malmberg, 1957 (Monogenea: Gyrodactylidae) on parr of Atlantic salmon (Salmo salar L.) in laboratory experiments. Syst. Parasitol. 20: 11-19.

MO T. A. 1994. Status of Gyrodactylus problems and research in Norway. In: A.W. Pike and J.W. Lewis (Eds.), Parasitic Diseases of Fish. Samara Publishing Dyfed, UK, pp. 43-58.

SHINN A.P., GIBSON D.I., SOMMERVILLE C. 2001: Morphometric discrimination of Gyrodactylus salaris Malmberg (Monogenea) from species of Gyrodactylus parasitising British salmonids using novel parameters. J. Fish Dis. 24: 83-97.

SHINN A.P., KAY J.W., SOMMERVILLE C. 2000: The use of statistical classifiers for the discrimination of species of the genus Gyrodactylus (Monogenea) parasitizing salmonids. Parasitology 120: 261-269.

SOLENG A., BAKKE T.A. 2001: The susceptibility of grayling, Thymallus thymallus to experimental infections with the monogenean Gyrodactylus salaris. Int. J. Parasitol. 31: 793-797.

STERUD E., MO T.A., COLLINS C.M., CUNNINGHAM C.O. 2002: The use of host specificity, pathogenicity, and molecular markers to differentiate between Gyrodactylus salaris Malmberg, 1957 and G. thymalli Zitnan, 1960 (Monogenea: Gyrodactylidae). Parasitology 124: 203-213.

ZIETARA M.S., LUMME J. 2002: Speciation by host switch and adaptive radiation in a fish parasite genus Gyrodactylus (Monogenea: Gyrodactylidae). Evolution 56: 2445-2458.

ŽITŇAN R. 1960: Gyrodactylus thymalli sp. nov. aus den Flossen der Äsche (Thymallus thymallus). Helminthologia 2: $266-269$.

Accepted 25 May 2004 